\title{
Globalization and the Modern Non-fiction
}

\author{
Svetlana Nikolayevna Mashkova \\ Kostanay State University, Kazakhstan, 110o11, Kostanay, Baitursynov Street, 47.
}

Received May 18, 2017; Revised July 15, 2017; Accepted July 17, 2017; Published August 06, 2017.

\begin{abstract}
The influence of globalization on the non-fictions of recent decades has caused its commercialization, rapid transfer to the center of the narrative of a completely different character who is often immoral, cynical, far from the Victorian type that dominated in previous decades, replacing it with simulacra. The article aims at exploring the consequences of the globalization development on literary texts including documentary ones, the emergence of new author's documentary concepts up to pseudo- and quasi-documentary, the transformation of the understanding of literary creativity as a phenomenon, and the comprehension of the literary process through the prism of cultural production and consumption of literary product.
\end{abstract}

Keywords: globalization, literary creation, documentary, literary production, non-fiction, quasidocumentary literature.

\section{Introduction}

Globalization, which is so much talked about in our time, is not that social phenomenon which saw the light only at the end of the last century. The origins of globalization processes should be sought in the distant past when people at the early stages of the development of civilization sought to integrate and synthesize knowledge acquired by their own hard experience about the world and the place of man in it. Each new invention of mankind (the appearance of wheel, steam engine, book printing, electric bulb, telephone, radio or television, the Internet) has contributed to the development of the processes of globalization and deepened the spiritual ties of different peoples. It was with the advent of printing that the systematic exchange among people improved the best achievements of literature and art. All of these contributed to the emergence of processes aimed at bringing together different types of people and different nations. I. Goethe introduced the notion of "world literature" (Weltliteratur). The translation business is gaining a powerful development. Due to translation, the best samples of fiction become much more readily available to the readers of different languages in different countries of the world and on different continents.

A powerful impetus to the processes of globalization in the latter decades of the twentieth century and at the beginning of the present was marked by large-scale changes that were irrevocable not only for the spiritual sphere of human activity but also primarily for politics, philosophy, finance, economics, media, information technology, advertising, etc.

(C) AesthetixMS 2016. This Open Access article is published under a Creative Commons Attribution Non-Commercial 4.0 International License (http://creativecommons.org/licenses/by-nc/4.0/), which permits non-commercial re-use, distribution, and reproduction in any medium, provided the original work is properly cited. For citation use the DOI. For commercial re-use, please contact editor@rupkatha.com. 


\section{The influence of globalization on the literary process}

Whereas the processes of globalization in the economy, financial sphere or politics are the subjects of study of many scientists who consider them in different aspects, research in the field of literature and art has not yet become a priority in the scientific literature. Scientists, especially philologists, stand today only on the threshold of the theoretical and historical-literary interpretation of such a phenomenon as globalization which undoubtedly has a number of positive consequences, primarily in the economic, energy and financial spheres. Significant breakthroughs in the sphere of information should also be added to the positive side, but it should be borne in mind that globalization bears many negatives for the social development of human civilization. "Of course, globalization cannot be stopped or canceled, we need to comprehend it and look for patterns in order to use the available potential and minimize the devastating consequences" [1, p. 7o].

I. Moisieva-Gusheva notes: "The notion of the global world is becoming closer, and the more interest is paid to the planetary identification, which is provoked by the ideas of transcultural vocalism" [2, p. 63]. "Scientific thought is still in the "beginning" of the way of profound comprehension of globalization, its tendencies in literature and art" [3, p. 67], writes B.N. Vorontsov. "The scale and multidimensionality of this process show that humanity has entered a new era of its development which will have the character of planetary changes" [4, p. 22], emphasizes B. Turner. M. Tlostanova writes:

"Globalization is not the first attempt of Western civilization to universalize the world at its own discretion (similar phenomena are observed in non-Western civilizations), we can treat the same way both the crusades and the colonialist practice. But globalization in the period of post-industrialization has its own specifics, which are symbolized by "Americanization" [5, p. 119].

In her opinion, under the influence of globalization, "the very understanding of literary creativity is changing. It loses the aura of sacredness and is understood as a market commodity" [5, p. 120].

First of all, it should be noted that globalization has affected primarily those areas of human activity where power and strength determine the ways of its implementation. This largely manifests itself in politics, economics, energy, finance, information and communication technologies, where the world's leading powers of the so-called first world strengthen their positions at the expense of the third world countries, reclaim their material resources (oil, gas, other minerals), plant loyal to world leaders' regimes, as evidenced by recent events in northern Africa, the Middle East, Central Asia, etc. The interests of the leading states, in which the "golden billion" resides, go beyond their own borders, acquire transnational signs. The leading states of the world are trying to transfer harmful or costly production to the underdeveloped states, where there is an excess of cheap labor. Significantly, growing contradictions are between wealth and poverty. Migration processes are developing in the world. Residents of the third world are increasingly seeking to penetrate into the territory of the highly-developed countries of the West, where they are also often used as cheap labor. Migration of labor in the processes of globalization also contributes to the development of denationalization, erosion or the complete loss of national differences, the destruction and disappearance of languages, especially of small peoples. The English language, in recent decades, has become dominant on different continents.

All of these have a direct relationship to literature. In particular, the literature of Europe and other continents becomes much harder to defend its identity, uniqueness, independence, the right to write in the native language; in fact, it is deprived of the right to the future. For example, 
according to Western scholars, "today in the Dutch literary field, many of recently issued new books are translations from foreign languages, mainly English" [6, p. 41]. All of these convincingly prove that translations from the English language and the English language itself gradually replace the national literary product, significantly restrict the scope of its use.

In the post-Soviet space, the Russian language has still a significant influence. This clearly manifests itself, for example, in Belarusian or Kazakh literature, and, to a lesser extent, in Ukrainian literature. However, in future, it can lead to an increase in the proportion of Englishspeaking literary product, which will supplant the Russian-speaking and later (or in parallel) the autochthonous ones.

\section{Globalization and modern non-fiction}

Modern authors, in their memoirs and biographies, often shock readers since they often describe the events that do not adorn themselves and their heroes. Thus, G. Grass in his memoirs "Peeling the Onion" [7] for the first time frankly writes about his SS-era. This fact concerns the youth of the Nobel laureate, but this frank confession shocked many admirers of the work of this talented writer not only in his homeland in Germany but also affected a wide range of readers in other countries of the world; it led to heated discussions about this in the press and on television. Some radical recipients of G. Grass' creativity required his total reassessment, deprivation of the writer of the Nobel Prize. And the radicals did not take into account the fact that in the novel, "Peeling the Onion", the author tried to recreate the complex process of comprehending the scale of Nazi crimes in World War II, the criminal role of SS troops in Hitler's atrocities, and all this happened to him only after the war and came not immediately, bringing to the world-famous artist a feeling of guilt and shame for the past and for his own short SS experience.

Shock value, erotic, obscene vocabulary, slang come to the forefront of new non-fiction more often. For example, this is evidenced by the biographical work of 2010 Nobel Laureate, a Peruvian writer M.V. Llosa "The Dream of the Celt" [8]. At first sight, a completely traditional work of a Latin American writer, overfilled with small details, hundreds of names of real characters, reference facts, shocks the reader by frequent references to the diaries of the main character Roger Casement, who reached high diplomatic posts in the British Empire, received state awards and then after ceasing to serve Great Britain, began to fight for the independence of Ireland. The diary (created or falsified by the British) discredits the character in the eyes of residents of Great Britain and its colony, Ireland, who were brought up in puritanical traditions, with naturalistic pictures of his multiple homosexual acts with different people, often with the society's scum in cheap hotels, night parks in different regions of the world where Roger Casement was thrown by fate. And instead of magical realism inherent in the Latin American novel, Mario Vargas Llosa's work presents a contradictory combination of naturalism, postmodernism, and neo-realism.

The powerful influence of globalization on the documentary literature of recent decades has affected its commercialization, the rapid transfer to the narrative center with a completely different hero, often immoral, cynical, far from the Victorian type that dominated in previous decades, replacing it often with simulacra, and sometimes turning into simulacrum the genre of documentary itself.

A striking example of such a "transformation" of the genre can be seen in the quasidocumentary novel-simulacrum of A. Nothomb "Life Form" (2010) [9], written in the form of letters, supposedly written to the author by an American soldier Melvin Mapple, who serves in 
American-occupied Baghdad, and the author's comments on the correspondence. And in this case, we are dealing not with a documentary-biographical work, but with a truly artistic one, which only imitates the authenticity of documents and facts related to the literature of nonfiction. We associate the appearance of such works with the consequences of globalization in literature.

The exposition of the work is extremely short; it seems to prepare readers for the perception of the text: "That morning I received a letter, which I had not yet received" [9, p. 5]. And then, there is the text of the letter of allegedly an ordinary of the American army, Melvin Mapple who, in parallel with the author, is one of the main characters in the novel. This letter is the outset of the work of A. Nothomb "Life Form". The action in the novel develops rapidly; although, the writer tries to artificially restrain it with her own comments aimed at determining the authenticity of the letter. Here, there is an American stamp, and here, it is an Iraqi stamp. A. Nothomb does not doubt in the handwriting of her correspondent: "He is an American, so simple and patterned, who I saw so many times when I was in the United States. And the style, it is so frontal, with its undoubted validity" [9, p. 6].

After some twists and turns correspondence became regular, and during her stay in the United States, the writer said everywhere that she was in correspondence with an American who served in Iraq. This contributed to the growth of the popularity of A. Nothomb; an article about her creative work appeared in the "Philadelphia Daily Report". In the following letters, the writer learns the details of the biography of Melvin Mapple before serving in the army, the circumstances of the commencement of service, but then the hero's story about himself resembles a simulacrum. He writes about the bulimia, which has been allegedly spreaded among the American soldiers in Baghdad.

The hero informs the writer that he has a catastrophically increased weight. Participation in battles raises the soldier's appetite; he wants to eat after a battle: "Everything starts with beer it's a cunning thing for weight, beer. You'll drain a jar or two, but there you can and something more important ... - all in plenty, eat from the belly. And we reap" [9, p. 23]. During the war, Melvin Mapple weights 18o kilograms. The American soldier calls his overweight the oriental name of Scheherazade: "This, of course, is not good for the real Scheherazade, who was, perhaps, slender, like a vine" [9, p. 25].

A. Nothomb uses intertextual communication through this name and connects her novel with the Arabian fairy tale "One Thousand and One Nights". Under the influence of the novel written in the author's mind, fantastic pictures appear: "I saw the torn-up bodies of Iraqis, explosions of shells, from which my head was split, and then - American soldiers, who ate up to colic, to reproduce in their wombs those explosions from the field fight. I saw a victorious procession of fat, I saw how it was given one position after another, and, accordingly, a form of an increasing size is needed. The front of the fat moved around the map. The US Army was a single entity, like a giant larva that feeds on the unknown, perhaps, Iraqi victims" [9, pp. 28-29].

Further, Melvin Mapple's letters are like a snowball which has been dropped from the mountain and increases in volume, and in a rising graduation unfold a fantastic picture of the drama of American soldiers who were seized by the epidemic of obesity. In the letters, an American soldier describes the fights of fat soldiers with thin men, who appeared in the American army in Iraq from time to time. The letter attempts to recreate the self-portrait of the hero of the novel: "... The worst is not the body - the face. Fat gives it an ugly expression, simultaneously skeptical, whiny, irritated and stupid. Who will like this?" [9, p. 48]. 
Melvin Mapple found the meaning of correspondence with the writer in that she needed for her profession someone else's experience, even if not personally experienced by her. In addition, he considered the process of his own obesity to be creative: "You know, Melvin, you are right: your excess weight is your creativity. You are on top of the wave of modern art. Begin to work without delay, because in your case the process is no less interesting than the result. In order for the leading body art admirers to recognize you as their own, I think you should also write down everything that you eat ... Think about creativity, which should be the only meaning of the artist's life" [9, p. 63].

A peculiar plug-in construction in the text of the novel is the reflection of A. Nothomb on the essence of epistolary creativity. Here she turns to her own childhood, because she began writing letters when she did not dream of becoming a writer:

"Since I was six, under the supervision of my parents I wrote a sheet a week from my mother's side to my grandfather whom I had never seen before" [9, p. 83].

"Then I understood the essence of the epistolary genre: it is a text intended for another. Novels, poems and other texts that can reach or not reach another. A letter without this other simply does not exist, its purpose and meaning is the phenomenon of the addressee" [9, p. 84].

According to A. Nothomb, the epistolary genre is like a tuneful ear; it is given not to everyone, but everyone can learn how to write letters. This plug-in design helps in motivating the correspondence of two different people - an American and a writer.

In one of the following letters, Melvin Mapple informed A. Nothomb what he had heard from the Americans who had returned home from Iraq, and it was unhappy:

"All the diseases, psychological and physical, which they suffered here, not only failed but, on the contrary, intensified. The doctors who are watching them now speak about the readaptation - they would use the same word if we left the prison. And, they say, after the release, they are better adapted. Former prisoners do not feel so alien to ordinary people, as we are now" [9, pp. 86-87].

It gives a portrait of the hero, made on the basis of a photo received by the writer:

"... Fresh fat, breaking through the continents of the formed tissues, swelled on the surface, to harden like a layer of fat for roast, to become, in turn, the basis for a new layer of fat. It was a victorious procession of obesity: the body was annexed by emptiness" [9, pp. 102-103].

The writer tensely considers an American photo paying attention to certain hypertrophied details of the characteristics of his portrait. It is clear that such a portrait in the depiction of the author of the novel, "Life Form", does not carry any pleasant feeling.

The absence of letters from the hero for a long time made the author of the novel make a request about his fate, to which A. Nothomb received an unexpected answer: "Melvin Mapple is unknown in the US Army" [9, p. 118]. But the writer learned that in Baghdad there is a man named Howard Mapple to whom she wrote a letter asking to learn something about the fate of Melvin. A letter from Howard impressed the writer with what was written on the same paper as Melvin's letters, the envelope and handwriting also coincided. In the letter, the address of Melvin Mapple at Baltimore was indicated. This information was somewhat that reassured A. Nothomb. She was sure that the American, apparently, was demobilized from the army and returned home. She 
wrote the last letter, and after a certain period of time, she received the answer: "Dear Amelie. I firmly decided not to write to you again. Your letter embarrassed me: how could you not hold a grudge against me? I was expecting a censure or something worse. Have not you realized yet that I do not deserve your friendship? Sincerely yours, Melvin" [9, p. 125].

This letter of the American surprised A. Nothomb because the respondent's handwriting changed, although she tried to explain this fact by his returning home, by changing the situation. However, soon the writer received a new letter from Melvin Mapple, which led her into a state of stupor; she could not do anything. Amelie did not know what to do, how to react to what she had learned from the letter. And yet, did she need to react at all?

Melvin Mapple wrote that he always deceived her during the correspondence: "I've never been in Iraq and I did not serve in the army at all" [9, p. 127]. Since he had no other business than sitting on the Internet, Melvin decided to have fun using his brother who served in Iraq and owed him a large sum of money, and so "agreed to rewrite my emails and send them to you. And he scanned your answers for me" [9, p. 127]. Correspondence with a famous writer became the main thing in life for the American, as his whole life was very poor in terms of events. Melvin only worried that Amelie Nothomb would ever inevitably ask for a photo. Being insured for this case, the protagonist had sent his brother to Baghdad beforehand a picture, which A. Nothomb saw. But her request to send a photo in military uniforms destroyed all Melvin's plans. He could not get a military uniform of XXXL size anywhere, and Brother Howard did not want to help him anymore, because he completely gave his debt: "He said that he worked for me not for nothing, but for $\$ 5$ a sheet or more, and he owes me nothing" [9, p. 128]. This stopped the correspondence.

After reflection, A. Nothomb sent a new letter to her correspondent, in which she congratulated him with a brilliant hoax. In response, Melvin Mapple said:

"All that I told you about my life before the age of 30 is true: I was wandering, lived without a roof over my head, was poor. But, when I reached the limit, I went not to the army but to my father and mother. I cannot imagine the worst humiliation" [9, p. 138].

His mother bought him a computer to create a site for a family car-care center. The work at the computer led to the fact that the hero spent time in front of the monitor most of the time. "The round-the-clock life on the Internet creates a feeling of complete unreality, so all the food I devoured for months kind of did not exist at all" [9, p. 143]. After reading the novels of A. Nothomb, Melvin Mapple decided to start a correspondence with her, thereby justifying his existence: "I think I seriously believed that I was carrying out military service in Baghdad" [9, p. 144]. The hero calls the ten years of correspondence with a famous writer "a form of life":

"I fell in love with this form of life and miss it. Correspondence worked as multiplication by simple division: I sent you a microscopic fraction of living matter, you read, and it doubled, your answer multiplied it even more" [9, p. 145].

Therefore, we can say that we are dealing with a scandalous quasi-rhetoric that mimics the author's correspondence with the protagonist who poses as an American soldier, but, in fact, never was in Iraq. The simulacrum is also his story about bulimia, which has allegedly a significant number of soldiers in Baghdad.

\section{Mass culture and the national literary process}


In general, under the influence of globalization, mass culture with far from the best samples of it penetrates powerfully into the national space of various states of the world, including Kazakhstan. Mass literature makes such works accessible to the general public, attracting more and more new readers. At the same time, it erodes their aesthetic tastes, as the reader in this case deals with works of a rather dubious aesthetic value, where the main criterion of success for the author and publisher is the receipt of high profits, the achievement of commercial success. [10]

In addition, most of these texts lose their national coloring, their stories are based on a stereotyped basis, and the characters become similar to the images of other, often, cult authors. Often, the basis of the storyline of such works is real stories with particularly audacious robberies, brutal murders, which are widely reported by the mass media. [11]

The intense process of de-canonization of real historical figures is unfolding. And it's not just about new biographies of well-known historical figures, say, Lenin, Stalin or other figures of the Soviet past; de-canonization sometimes involves figures of prominent figures in Kazakh science or culture. No one has ever calculated and predicted this powerful impact of mass culture in the spiritual space of Kazakhstan and its consequences in the future. However, now, it becomes clear that, along with positive moments, globalization brings many dangers to the literature: first of all, orienting readers with unpretentious aesthetic tastes of texts based on the reflection of primitive physiological needs, low human instincts, violence, criminal, religious and other subcultures.

Literary language is increasingly being supplanted by colloquial language with profanity. Another threat is the demonstration of de-heroization, de-canonization of the past ignoring the national and historical features of the development of the literature of this or that people, its traditions, customs, and rituals. Finally, the extreme form of globalization leads to the disappearance of individual nations and the erosion of national characteristics. At the same time, the aesthetic component of literature is increasingly being taken into account. Particularly, it concerns the documentary literature, especially memoirs and artistic and biographical works. The texts, where outstanding figures of culture, art, scientists, and sportsmen are represented, are gradually being pushed to the side of civilization, they become marginal. [13]

Instead, the dominance of mass culture is brought to the forefront by the cruel dictators, on whose consciences there are millions of human lives, serial killers, organizers of resonant robberies, the godfathers of the mafia, religious fanatics and extremists, representatives of the criminal subculture, people who have serious problems with the law. Here often for commercial writers and publishers purely commercial interests play a leading role. [14]

Publishers assume that the memoir or biographical book as a commodity should be quickly implemented, have commercial success and bring superfast profits. The author of such a work, in this case, turns into a product of commerce, for which PR companies are needed. The model of the relationship between the author and the reader, still characteristic of Western countries, begins to take root in the post-Soviet space. And in this way globalization negatively affects the content and artistic quality of the documentary book. [15]

With this approach, the specific features that give grounds for attributing the memoir or biographical work to a particular national literature are necessarily disappearing. Heroes of biographical works turn out to be cosmopolitan and extremely similar to each other. They live according to the standards of their prototypes, which, under the conditions of globalization and in pursuit of super profits, do not observe any morality; they easily commit all sorts of crimes. 


\section{Conclusion}

Non-fiction (novelized biography, memoirs, autobiography) of the last decades is rapidly changing under the influence of globalization in the world. This is especially true about those genres that non-fiction literature has borrowed from the epic, primarily from the novel and the story. In the center of their narrative, there appears a completely different hero who differs significantly from the "fiery revolutionary" of the Soviet era and does not fit into the canon of the Western hero of the Victorian type. Such a hero has a complex personal destiny; he is capable of heroic deeds, but he is not deprived of ordinary human vices. The author gives him deep inner thoughts, the ability to analyze his experience from the point of view of the new time. Authors try not to avoid previously tabooed moments of biography; they add certain portions of eroticism that sometimes gravitate toward pornography; at times, fill the work with elements of quasibiography. They have not bypassed the possibilities of experiments with the form, as a result of which their works clearly go beyond the boundaries of genre canons.

The influence of globalization on non-fiction of recent decades requires further careful consideration by literary scholars and thorough study. At the same time, it becomes clear that national non-fiction can survive (like fiction in general) in the context of close international contacts if it promotes the development of the national identity, the cultural strengthening of its own people.

A regular study of the processes of globalization in literature, particularly in documentary, will certainly raise the question of the need to search for other research methodologies that can objectively be only interdisciplinary. A scientist engaged in such a study should be well versed not only in the art of the word but also in economics, financial issues, in the processes that take place in historical science, philosophy, sociology, culturology, anthropology, etc.

\section{References}

1. Kelle, V. Z. (2005). Protsessy globalizatsii i dinamika kultury [The Processes of Globalization and the Dynamics of Culture]. Znanie. Ponimanie. Umenie, 1, 69-76.

2. Moisieva-Gusheva, Ya. (2006). Globalizatsiya i novye tendentsii v literature [Globalization and New Trends in Literature]. Slavyanovedenie, 6, 62-67.

3. Vorontsov, B.N. (2002). Fenomen massovoi kultury: etiko-filosofskii analiz [Phenomenon of Mass Culture: Ethical and Philosophical Analysis]. Filosofskie nauki, 3, 110-123.

4. Turner, B. (1990). Two Faces of Sociology: Global or National in Global Culture. London.

5. Tlostanova, M. (200o). Problema multikulturalizma i literatura SShA kontsa XX v. [The Problem of Multiculturalism and the Literature of the United States of the Late Twentieth Century]. Moscow.

6. Van Rees, K. (2012). Field, Capital and Habitus: A Relational Approach to "Small" Literatures. In G.B. Kohler, P. Navumenka, \& R. Gruettemeier (Eds.), Kleinheit als Spezifik: Beiträge zu einer feldtheoretischen Analyse der belarussischen Literatur im Kontext "kleiner" slavischen Literaturen (pp. 1556). Oldenburg: BIS-Verlag der Carl von Ossietzky Universität Oldenburg.

7. Grass, G. (2008). Lukovitsa pamyati [Peeling the Onion]. Moscow: Inostranka, 592 p.

8. Vargas, M.L. (2012). Son kel'ta [The Dream of the Celt]. Moscow: Foreigners, $400 \mathrm{p}$.

9. Notomb, A. (2011). Forma zhizni [Life Form] (N. Hotinskaya, Trans.). Moscow: Inostranka. (p. 16o). 
10. Paul H. F. (2009). Popular Culture and Literature //Encyclopedia of Marine Mammals (Second Edition), Pages 898-913

11. Ryan Poirier, Et al. (2007). Exploring adolescent development through the use of popular non-fiction novels//Teaching and Teacher Education, Volume 23, Issue 8, November 2007, Pages 1345-1349

12. Chernyak, M.A. (2009). Massovaya literatura XX veka: Uchebnoe posobie [Mass Literature of the Twentieth Century: Student Book]. Moscow: Nauka.

13. Antofi, S. (2013). The Exile Literature of Memoirs - Debates, Dilemmas, Representative Texts and their Formative-Educative Effects//Procedia - Social and Behavioral Sciences, Volume 93, 21 October 2013, Pages 29-34

14. Friedmann, A. (2010). Documentary and Nonfiction Narrative/Writing for Visual Media (Third Edition), 2010, Pages 137-153

15. Sapiro, G. (2016). The metamorphosis of modes of consecration in the literary field: Academies, literary prizes, festivals//Poetics, Volume 59, December 2016, Pages 5-19 